\title{
Application and optimization of solid-state fermentation process for enhancing polygalacturonase production by Penicillium expansum
}

\author{
Mingming Zhu ${ }^{1}$, Hongju He ${ }^{1 *}$, Mingtao Fan ${ }^{2}$, Hanjun $\mathrm{Ma}^{1}$, Haiwei Ren ${ }^{3}$, Jie Zeng ${ }^{1}$, Haiyan Gao ${ }^{1}$ \\ (1. School of Food Science, Henan Institute of Science and Technology, Xinxiang 453003, China; \\ 2. College of Food Science and Engineering, Northwest A\&F University, Yangling 712100, China; \\ 3. School of Life Science and Engineering, Lanzhou University of Technology, Lanzhou 730050, China)
}

\begin{abstract}
Penicillium expansum 3.5425 was applied in solid-state fermentation (SSF) of agricultural wastes for polygalacturonase biosynthesis. Among various carbon additives, apple pomace was most suitable for the biosynthesis of polygalacturonase $(1440.57 \mathrm{U} / \mathrm{g})$. Optimization of medium parameters using rotational orthogonal design (ROD) experiment combined with optimal fermentation conditions resulted in a 2.72-fold increase in the polygalacturonase production. By using ammonium sulphate precipitation, ion-exchange and gel-permeation chromatography, the polygalacturonase produced by P. expansum 3.5425 was finally purified which had specific activity of $19269 \mathrm{U} / \mathrm{mg}$ and molecular weight of $30 \mathrm{kDa}$. The enzyme was remarkably active in the $\mathrm{pH}$ range of $3-5$ and at $50^{\circ} \mathrm{C}$, which makes it more acceptable in the industrial application. Besides, partially purified polygalacturonase $(875.15 \mathrm{U} / \mathrm{mL})$ was used for apple juice clarification and the clarity at $0.4 \mathrm{~mL} / \mathrm{kg}$ was maximum, which reveals a great potential of polygalacturonase in food industry.
\end{abstract}

Keywords: solid-state fermentation (SSF), polygalacturonase, Penicillium expansum, juice clarification, agricultural wastes DOI: $10.25165 /$ j.ijabe.20181106.3673

Citation: Zhu M M, He H J, Fan M T, Ma H J, Ren H W, Zeng J, et al. Application and optimization of solid-state fermentation process for enhancing polygalacturonase production by Penicillium expansum. Int J Agric \& Biol Eng, 2018; 11(6): 187-194.

\section{Introduction}

In the industrial area, pectinase is a common term of enzyme groups providing three different catalytic activities (hydrolysis, de-esterification or trans-elimination) which catalyze various pectin and pectic substances ${ }^{[1,2]}$. Pectin, which present in vegetables and fruits in large amount, remains in the pulp during extraction and causes cloudiness in juices. Commercial pectinases are therefore widely applied in juice extraction and clarification of sparkling clear juices (apple, grape and pear juices), cloudy juices (tomato, citrus, prune and nectars) and unicellular products, to preserve the integrity of the plant cells through selective hydrolysis of polysaccharides of the middle lamella ${ }^{[3-5]}$. Polygalacturonase, as one of the most important pectinases, has been widely used in fruit or vegetable juices processing procedures, including maceration, liquefication, extraction, and clarification.

Nowadays many researchers have focused on the fungal polygalacturonase production by applying solid-state fermentation (SSF) instead of submerged fermentation. SSF, as an increasingly

\section{Received date: 2017-07-26 Accepted date: 2018-05-04}

Biographies: Mingming Zhu, PhD, research interests: processing and storage of agricultural products, protein purification, Email: happyzhumingming@126.com; Mingtao Fan, Professor, research interests: food biotechnology, microbial fermentation, Email: fanmt@ @wsuaf.edu.cn; Hanjun Ma, Professor, research interests: processing and storage of agricultural products, Email: xxhjma@126.com; Haiwei Ren, PhD, research interests: food nutrition and functional food, Email: rhw52571119@163.com; Jie Zeng, Professor, research interests: agricultural products processing and conversion, Email: zengjie623@ 163.com; Haiyan Gao, Associate Professor, research interests: agricultural products processing and conversion, Email: gaohaiyan127@163.com.

*Corresponding author: Hongju He, Professor, research interests: food nondestructive analysis and detection. School of Food Science, Henan Institute of Science and Technology, Xinxiang 453003, China. Tel: +86-15637320837, Email: hongju_he007@126.com. growing technology for enzyme production, has a series of advantages over submerged fermentation such as less water and solvent requirement, more favorable conditions for fungal growth, lower liquid waste generation, higher concentration and larger amount of enzyme production. These advantages achieved special economic interest from those industries with abundance of biomass and agro-industrial residues ${ }^{[6,7]}$, in particular fruits processing industry. Various agro-industrial residues such as mango peel ${ }^{[8]}$, banana peel ${ }^{[9]}$, orange peel ${ }^{[10]}$, grape pomace ${ }^{[11]}$, coffee beans ${ }^{[12]}$, papaya pee ${ }^{[13]}$, wheat bran ${ }^{[4]}$ and apple pomace ${ }^{[14]}$ have been considered as preferable SSF substrates (carbon and energy sources) to produce polygalacturonase due to their availability and low-cost. To maintain microbial growth and enzymatic synthesis in SSF, some important factors such as moisture content, carbon and nitrogen sources, inoculums load, incubation time, temperature, $\mathrm{pH}$ and solid/liquid ratio should be optimized $^{[15]}$. The selection and optimization of substrates and culture condition are also necessary to decrease industrial costs for enzymatic biosynthesis ${ }^{[9]}$.

At present, microbial species such as Aspergillus have been well-acknowledged for polygalacturonase production ${ }^{[10]}$. Other fungal species used for producing polygalacturonases are Penicillium, Trichoderma, Fusarium and Rhizopus spp. ${ }^{[16]}$. In recent years, Penicillium, as a genus of ascomycetous fungi, has demonstrated great potential of producing polygalacturonase and received extensive attention in polygalacturonase biosynthesis ${ }^{[7]}$. This study attempted to apply Penicillium expansum 3.5425 in SSF with wheat bran and apple pomace as carbon substrates to produce polygalacturonases. Based on the medium composition and fermentation conditions, the parameters influencing polygalacturonase production were optimized and the polygalacturonase yield was enhanced. The purification and characterization of the polygalacturonase and its performance in 
apple juice clarification were also carried out to facilitate industrial application.

\section{Materials and methods}

\subsection{Microorganism}

Penicillium expansum 3.5425 was obtained from China General Microbiological Culture Collection Center. The strain was maintained on agar slant medium at $4^{\circ} \mathrm{C}$ and subcultured every three months.

\subsection{Substrates}

Apple pomace, orange peel, wheat bran, corn bran and bean pulp were used as substrates in SSF. Fresh apple pomace was provided by Haisheng Fresh Fruit Juice Co., Ltd. (Shaanxi, China) and mainly composed of peel, core, seed, calyx, stem and exhausted soft tissues. Fresh orange peel was obtained from a local supermarket (Yaling, Shaanxi, China). Wheat bran (residues from the production of wheat flour), corn bran (residues form the production of corn flour) and bean pulp were supplied by a local factory (Yaling, Shaanxi, China) and passed through a 40-mesh sieve before use.

\subsection{Inoculum preparation}

The Penicillium expansum 3.5425 strain was activated on potato dextrose agar (PDA) medium containing potato $300 \mathrm{~g} / \mathrm{L}$, glucose $20 \mathrm{~g} / \mathrm{L}$, agar $20 \mathrm{~g} / \mathrm{L}$. The initial $\mathrm{pH}$ of the PDA medium was natural. After cultivation, a loop of spores was collected from the PDA plate and then transferred into a $250 \mathrm{~mL}$ Erlenmeyer flask containing sterilized distilled water. A suspension containing $10^{6}$ spores $/ \mathrm{mL}$ was prepared and stored at $4^{\circ} \mathrm{C}$.

\subsection{Solid-state fermentation (SSF)}

The basic medium consisted of wheat bran $(5 \mathrm{~g})$ and distilled water $(30 \mathrm{~mL})$ with $\left(\mathrm{NH}_{4}\right)_{2} \mathrm{SO}_{4}(1.20 \%), \mathrm{KCl}(0.15 \%), \mathrm{MnSO}_{4}$ $(0.30 \%)$ and Tween-80 $(0.04 \%)$. The substrates were transferred into $250 \mathrm{~mL}$ Erlenmeyer flasks and set at natural $\mathrm{pH}$. Apple pomace, orange peel, corn bran and bean pulp were used as carbon additives in SSF. All the agricultural wastes were air-dried, crushed into powder, washed three times with sterile distilled water, oven-dried at $60^{\circ} \mathrm{C}$, grounded, passed through a 40-mesh sieve and then stored until use. The above wastes $(5 \mathrm{~g})$ were respectively added to the basic medium and the flasks were sealed with hydrophobic cotton and autoclaved at $121^{\circ} \mathrm{C}$ for $20 \mathrm{~min}$. After cooling to room temperature, the medium was inoculated with $2 \times 10^{6}$ spores/g dry substrate, carefully mixed under aseptic conditions, and then incubated in an incubator at $28^{\circ} \mathrm{C}$ for $96 \mathrm{~h}$ in static mode. The basic medium inoculated with $2 \times 10^{6}$ spores $/ \mathrm{g}$ dry substrate was used as control. All samples were taken to assess the enzyme production.

\subsection{Pectinase extraction}

After the SSF completed, sterile water was added into the Erlenmeyer flask (three times of the culture medium weight). The new mixture was mixed thoroughly on a rotary shaker $(150 \mathrm{rpm})$ at a constant temperature of $30^{\circ} \mathrm{C}$ for $3 \mathrm{~h}$. Then, the mixture was filtered through a four-layer muslin cloth. The collected solution was used as the crude enzyme solution and the total volume was recorded.

\subsection{Enzyme activity and protein determination}

The pectinase activity was measured using dinitrosalicylate assay described by Miller ${ }^{[17]}$. In specific, $1 \mathrm{~mL}$ pectin solution $(1.0 \%)$ was transferred into a test tube and kept in a water bath at $50^{\circ} \mathrm{C}$ for $5 \mathrm{~min}$. Then, $50 \mu \mathrm{g}$ crude enzyme solution was added and the tube was kept at $50^{\circ} \mathrm{C}$ for $30 \mathrm{~min}$. The reaction was terminated by adding $2 \mathrm{~mL} \mathrm{3,5-dinitrosalicylic} \mathrm{acid} \mathrm{(DNSA)} \mathrm{and}$ keeping the tube in boiling water for 5 min. After rapid cooling in an ice bath, the final volume of solution was adjusted to $25 \mathrm{~mL}$ by distilled water. A control solution was prepared under the same reaction conditions with inactivated enzyme. The absorbance of the diluted solution was determined at $540 \mathrm{~nm}$. One unit of pectinase activity was defined as the amount of enzyme required for liberating $1 \mu \mathrm{g}$ of galacturonic acid in milliliters per minute under the above conditions, using a standard curve obtained from the galacturonic acid.

The protein content was measured according to the method of Bradford $^{[18]}$, using Bovine albumin as the standard.

2.7 Optimization of medium components and statistical analysis

A rotational orthogonal design (ROD) with three variables including wheat bran/apple pomace (w/w), $\left(\mathrm{NH}_{4}\right)_{2} \mathrm{SO}_{4}(\%)$ and solid/liquid ratio $(\mathrm{g} / \mathrm{v})$ at five levels (preliminary experiments were carried out to determine the parameter range) was carried out to explore the role of interacting variables and maximize enzymatic production. The range and the level of the variables are given in Table 1.

Table 1 Variables and their levels in the rotational orthogonal experiment

\begin{tabular}{|c|c|c|c|c|c|c|}
\hline \multirow{2}{*}{$\begin{array}{c}\text { Independent } \\
\text { variables }\end{array}$} & \multirow{2}{*}{$\begin{array}{l}\text { Symbol } \\
\text { code }\end{array}$} & \multicolumn{5}{|c|}{ Range and levels } \\
\hline & & -1.682 & -1 & 0 & 1 & 1.682 \\
\hline $\begin{array}{l}\text { Wheat bran/Apple } \\
\text { pomace } / \mathrm{w} \cdot \mathrm{w}^{-1}\end{array}$ & $X_{1}$ & $6.7: 3.3$ & $6: 4$ & $5: 5$ & $4: 6$ & $3.3: 6.7$ \\
\hline$\left(\mathrm{NH}_{4}\right)_{2} \mathrm{SO}_{4} / \%$ & $X_{2}$ & 0.86 & 1.0 & 1.2 & 1.4 & 1.54 \\
\hline Solid/liquid ratio/g $\cdot \mathrm{v}^{-1}$ & $X_{3}$ & $1: 1.3$ & $1: 2$ & $1: 3$ & $1: 4$ & $1: 4.7$ \\
\hline
\end{tabular}

The response variable (polygalacturonase activity) was fitted by a mathematical model. Once the experiments were completed, the results were fitted with a second-order polynomial function shown as follow:

$$
\begin{aligned}
Y= & \alpha_{0}+\alpha_{1} X_{1}+\alpha_{2} X_{2}+\alpha_{3} X_{3}+\alpha_{12} X_{1} X_{2}+\alpha_{13} X_{1} X_{3}+ \\
& \alpha_{23} X_{2} X_{3}+\alpha_{11} X_{1}^{2}+\alpha_{22} X_{2}^{2}+\alpha_{33} X_{3}^{2}
\end{aligned}
$$

where, $Y$ was polygalacturonase activity; $\alpha_{0}$ was the intercept term; $\alpha_{1}, \alpha_{2}$ and $\alpha_{3}$ were linear coefficients; $\alpha_{12}, \alpha_{13}$ and $\alpha_{23}$ were interaction coefficients; $\alpha_{11}, \alpha_{22}$ and $\alpha_{33}$ were squared coefficients, and $X_{1}, X_{2}$ and $X_{3}$ were coded independent variables. The experimental design and regression analysis were performed using software DPS 7.05. The statistical analysis was performed using analysis of variance (ANOVA).

\subsection{Optimization of fermentation conditions}

After optimizing the medium components, fermentation conditions were further established to enhance the polygalacturonase production under the optimum values of wheat brans/apple pomace, $\left(\mathrm{NH}_{4}\right)_{2} \mathrm{SO}_{4}$ and solid/liquid ratio. The SSF process parameters were set as follows: initial $\mathrm{pH}(4.0,5.0$, nature, 6.0, 7.0 and 8.0), fermentation time $(2 \mathrm{~d}, 3 \mathrm{~d}, 4 \mathrm{~d}, 6 \mathrm{~d}, 8 \mathrm{~d}$ and $10 \mathrm{~d})$, the medium volume $(5-20 \mathrm{~g} / 250 \mathrm{~mL}$, means $5-20 \mathrm{~g}$ mediums were placed into a $250 \mathrm{~mL}$ flask, respectively) and inoculum load $\left(10^{5}-2 \times 10^{7}\right.$ spores/g dry substrate). The approach was adopted to measure one variable, independent of the others, and the established parameters were applied to the rest of the study.

\subsection{Purification and characterization of polygalacturonase}

\subsubsection{Purification}

The crude enzyme solutions were centrifuged at $4^{\circ} \mathrm{C}$, $6000 \mathrm{r} / \mathrm{min}$ for $20 \mathrm{~min}$ and the target enzyme extracts remained in supernatants. Then, ammonium sulfate $(516 \mathrm{~g} / \mathrm{L})$ was added to the supernatants and the whole mixture was kept at $4^{\circ} \mathrm{C}$ for $24 \mathrm{~h}$. 
The precipitate was obtained by centrifugation at $6000 \mathrm{r} / \mathrm{min}$ for $20 \mathrm{~min}$ and dissolved in distilled water. The individual fractions were desalted with a dialysis bag (cutoff $7 \mathrm{kDa}$, Union Carbide Co., Houston, Texas, USA) in $500 \mathrm{~mL}$ of distilled water at $4^{\circ} \mathrm{C}$, with three buffer changes at $4 \mathrm{~h}$ intervals. $\mathrm{BaCl}_{2}$ was used to detect whether the salt was removed completely. The target enzyme solution was collected and concentrated in a freeze dryer (Coolsafe110-4; Gene Co., Ltd.). Then the solution was loaded onto a HiTrap CMFF column $(5 \times 1 \mathrm{~mL}$, GE Healthcare Life Science, Amashia, Sweden) at a flow rate of $1 \mathrm{~mL} / \mathrm{min}$. The elution was carried out using three gradients of $\mathrm{NaCl}(0,0.5 \mathrm{M}$ and $1 \mathrm{M})$ in the $20 \mathrm{mM}$ phosphate buffer ( $\mathrm{pH} \mathrm{6.8).} \mathrm{The} \mathrm{peak} \mathrm{fractions}$ were collected under three gradients, respectively, and analyzed for polygalacturonase activity and protein content. The active fractions were pooled, concentrated and subjected to a Sephadex G-75 column (13 $\mu \mathrm{m}, 10 \times(300-310) \mathrm{mm}$, GE Healthcare Life Science, Amashia, Sweden) which had been pre-equilibrated with distilled water. The elution with distilled water was then performed at a flow rate of $1 \mathrm{~mL} / \mathrm{min}$. Fractions containing the polygalacturonase activity were collected for further study.

2.9.2 Sodium dodecyl sulfate-polyacrylamide gel electrophoresis (SDS-PAGE)

The purity and molecular weight of polygalacturonase were determined by SDS-PAGE. A gel composed of $10 \%$ and 5\% polyacrylamide were prepared for separation and concentration, respectively. Protein bands were visualized by staining with silver in gels and their relative positions were analyzed by Bio-Rad Gel system. Protein marker with different molecular weights was used for SDS-PAGE.

2.9.3 Effects of temperature, $\mathrm{pH}$ and cations on polygalacturonase activity

To determine the effect of temperature on the enzyme activity, the reaction was performed from 20 to $80^{\circ} \mathrm{C}$ in water bath. The influence of $\mathrm{pH}$ on the enzyme activity was measured using $20 \mathrm{mM}$ citrate- $\mathrm{NaOH}$ buffers of different $\mathrm{pHs}$ from 2 to 10 . Chloride salts $\left(\mathrm{KCl}, \mathrm{NaCl}, \mathrm{CaCl}_{2}, \mathrm{MgCl}_{2}, \mathrm{MnCl}_{2}, \mathrm{CuCl}_{2}, \mathrm{ZnCl}_{2}, \mathrm{FeCl}_{2}\right.$ and $\mathrm{AlCl}_{3}$ ) were applied to determine the influence of cations on the enzymatic activity with three concentrations $(0.5 \mathrm{mM}, 1.0 \mathrm{mM}$ and $1.5 \mathrm{mM})$. At each assay, controls were prepared without enzyme as described above.

2.9.4 Kinetic studies

The Michaelis-Menten constant $\left(K_{\mathrm{m}}\right)$ and the maximum rate $\left(V_{\max }\right)$ of polygalacturonase were determined by using various concentrations of pectin (from $2 \mathrm{mg} / \mathrm{mL}$ to $14 \mathrm{mg} / \mathrm{mL}$ ). The reaction was performed at $\mathrm{pH} 5.0$ and $50^{\circ} \mathrm{C} . \quad K_{\mathrm{m}}$ and $V_{\max }$ were calculated from the Lineweaver-Burk double-reciprocal plot.

\subsection{Apple juice clarification}

\subsubsection{Raw apple juice preparation}

Apples (Fuji) were harvested and stored at room temperature for one week. Then, the apples were cut to cubes, mashed in a grinder and manually pressed using double layer cheesecloth to obtain raw or unclarified apple juice. Ascorbic acid was added in the extracted juice to the final concentration of $1.0 \mathrm{~g} / \mathrm{L}$. Aliquots of this juice were pasteurized $\left(10 \mathrm{~min}\right.$ at $\left.85^{\circ} \mathrm{C}\right)$ and then immediately cooled to $50^{\circ} \mathrm{C}$.

2.10.2 Optimization of apple juice clarification conditions

In order to obtain the optimum addition amounts of polygalacturonase for clarification, the partially purified enzyme after ammonium sulfate treatment $(875.15 \mathrm{U} / \mathrm{mL})$ were added to apple juice from 0 to $1 \mathrm{~mL} / \mathrm{kg}$. The juice clarity was determined by measuring \% Transmittance as described by Dey and
Banerjee $^{[19]}$. The mixture of juice and enzyme was incubated at $50^{\circ} \mathrm{C}$ for $1 \mathrm{~h}$ and $\%$ Transmittance at $660 \mathrm{~nm}$ was determined spectrophotometrically. Two milliliter enzymatic reaction solution was taken and mixed with acidified alcohol which contained $4 \mathrm{~mL}$ of $10 \mathrm{~mL} / \mathrm{L} \mathrm{HCl}$ for $20 \mathrm{~min}$ to determine the decrease of pectin (\%). The decrease of pectin (\%) was defined as $\%$ Transmittance at $660 \mathrm{~nm}$. In the control, no enzyme was applied.

After established the polygalacturonase concentration, other parameters including $\mathrm{pH}(2.5-7.0)$, temperature $\left(30^{\circ} \mathrm{C}-70^{\circ} \mathrm{C}\right)$ and incubation time (10-180 $\mathrm{min})$ were also optimized using the same method as described above.

\section{Results and discussion}

\subsection{Production of polygalacturonase from different agricultural wastes}

Improper disposal of solid agricultural residues always causes waste of resources and environmental pollution. Biological conversion has been considered as a better way to deal with the agricultural wastes. For instance, banana peels, wheat straw, wheat bran, sugarcane bagasse, rice straw and soybean hulls have been used as the substrates for enzyme production ${ }^{[2,20]}$. The natural solid substrate in SSF not only offers the nutrients but also acts as the anchorage for the microbial cells ${ }^{[21]}$. It is better to select a low-cost solid substrate which provides all necessary nutrients for microbial growth and desired enzyme production. In this study, agricultural wastes including apple pomace, orange peel, corn bran and bean pulp were tested as carbon additives for polygalacturonase production by Penicillium expansum 3.5425. Apple pomace was found to dramatically promote the enzyme activity ( $1440.57 \mathrm{U} / \mathrm{g}$ dry substrate) which increased by about $20 \%$ compared with the basic medium (only wheat bran) (Figure 1). Besides, selection of industrially pertinent microbes is also important. In preliminary work, Penicillium expansum 3.5425 was found to be superior in polygalacturonase production.

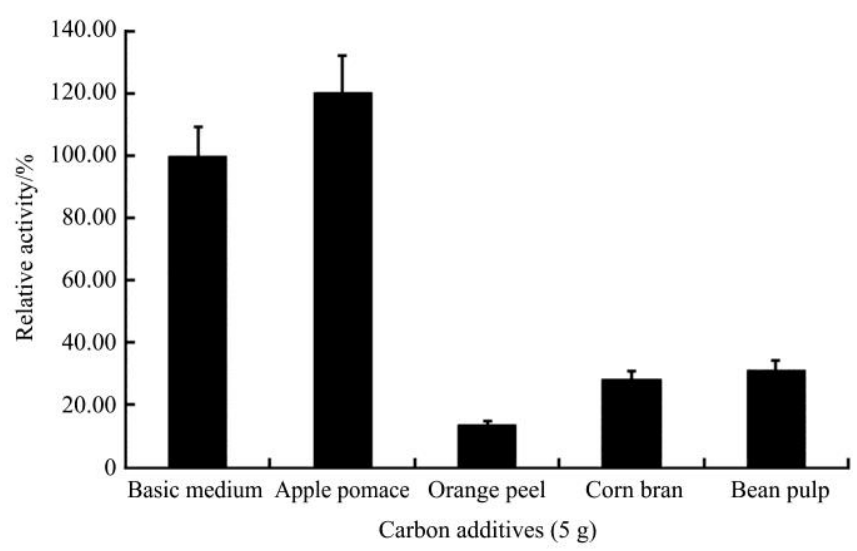

Figure 1 Activity of polygalacturonase on various agricultural wastes as carbon additives

Apple pomace is rich in sugars ${ }^{[22]}$, especially pectin, which is the main factor enhancing the production of polygalacturonase. The other agricultural residues, however, showed inhibiting effects on the enzyme activity to a certain degree (Figure 1), which might be due to some factors that inhibit the fungi growth.

\subsection{Quadratic rotational orthogonal experiment}

Wheat brans/apple pomace, $\left(\mathrm{NH}_{4}\right)_{2} \mathrm{SO}_{4}$ and solid/liquid ratio were firstly selected as major effective components for the medium 
optimization. The coded values of factors, design and results of the experiment are listed in Table 2.

Table 2 Experimental design and the results of the rotational orthogonal design

\begin{tabular}{|c|c|c|c|c|c|c|c|}
\hline \multirow{3}{*}{ Run } & \multicolumn{6}{|c|}{ Variables } & \multirow{3}{*}{$\begin{array}{l}\text { Polygalacturonase } \\
\text { activity } \\
/ \mathrm{U} \cdot \mathrm{g}^{-1} \text { dry substrate }\end{array}$} \\
\hline & \multicolumn{3}{|c|}{ Coded levels } & \multicolumn{3}{|c|}{ Actual levels } & \\
\hline & $X_{1}$ & $X_{2}$ & $X_{3}$ & $X_{1}$ & $X_{2}$ & $X_{3}$ & \\
\hline 1 & 1 & 1 & 1 & $4: 6$ & 1.4 & $1: 4$ & 2088.63 \\
\hline 2 & 1 & 1 & -1 & $4: 6$ & 1.4 & $1: 2$ & 1598.73 \\
\hline 3 & 1 & -1 & 1 & $4: 6$ & 1.0 & $1: 4$ & 2869.04 \\
\hline 4 & 1 & -1 & -1 & $4: 6$ & 1.0 & $1: 2$ & 2769.34 \\
\hline 5 & -1 & 1 & 1 & $6: 4$ & 1.4 & $1: 4$ & 2005.53 \\
\hline 6 & -1 & 1 & -1 & $6: 4$ & 1.4 & $1: 2$ & 3217.36 \\
\hline 7 & -1 & -1 & 1 & $6: 4$ & 1.0 & $1: 4$ & 1962.18 \\
\hline 8 & -1 & -1 & -1 & $6: 4$ & 1.0 & $1: 2$ & 1815.51 \\
\hline 9 & -1.6818 & 0 & 0 & $6.7: 3.3$ & 1.2 & $1: 3$ & 2444.8 \\
\hline 10 & 1.6818 & 0 & 0 & $3.3: 6.7$ & 1.2 & $1: 3$ & 2960.86 \\
\hline 11 & 0 & -1.6818 & 0 & $5: 5$ & 0.86 & $1: 3$ & 3704.26 \\
\hline 12 & 0 & 1.6818 & 0 & $5: 5$ & 1.54 & $1: 3$ & 1750.3 \\
\hline 13 & 0 & 0 & -1.6818 & $5: 5$ & 1.2 & $1: 1.3$ & 1603 \\
\hline 14 & 0 & 0 & 1.6818 & $5: 5$ & 1.2 & $1: 4.7$ & 988.18 \\
\hline 15 & 0 & 0 & 0 & $5: 5$ & 1.2 & $1: 3$ & 2361.94 \\
\hline 16 & 0 & 0 & 0 & $5: 5$ & 1.2 & $1: 3$ & 3141.87 \\
\hline 17 & 0 & 0 & 0 & $5: 5$ & 1.2 & $1: 3$ & 2726.86 \\
\hline 18 & 0 & 0 & 0 & $5: 5$ & 1.2 & $1: 3$ & 2605.38 \\
\hline 19 & 0 & 0 & 0 & $5: 5$ & 1.2 & $1: 3$ & 2531.77 \\
\hline 20 & 0 & 0 & 0 & $5: 5$ & 1.2 & $1: 3$ & 2836.68 \\
\hline 21 & 0 & 0 & 0 & $5: 5$ & 1.2 & $1: 3$ & 3226.86 \\
\hline 22 & 0 & 0 & 0 & $5: 5$ & 1.2 & $1: 3$ & 2946.49 \\
\hline 23 & 0 & 0 & 0 & $5: 5$ & 1.2 & $1: 3$ & 2161.2 \\
\hline
\end{tabular}

By weeding out the nonsignificant factors $(\alpha=0.10)$, the relationship between polygalacturonase activity $(Y)$ and ratio of wheat bran/apple pomace $\left(X_{1}\right),\left(\mathrm{NH}_{4}\right)_{2} \mathrm{SO}_{4}\left(X_{2}\right)$, solid/liquid ratio $\left(X_{3}\right)$ was obtained and expressed by Equation (2) as follow:

$$
\begin{aligned}
Y= & 2724.87476-277.66101 X_{2}-489.69100 X_{3}{ }^{2}- \\
& 424.52750 X_{1} X_{2}
\end{aligned}
$$

The statistical significance of Equation (2) was controlled by $F$ value, and the ANOVA for the quadratic model was given in Table 3.

Table 3 Partial regression coefficient estimates of the regression equation

\begin{tabular}{cccccc}
\hline Source & Sum of squares & DF & Mean square & $F$ value & $p$ value \\
\hline$X_{1}$ & 104226.5317 & 1 & 104226.5317 & 0.5715 & 0.4632 \\
$X_{2}$ & 1052883.8998 & 1 & 1052883.8998 & 5.7730 & 0.0319 \\
$X_{3}$ & 166859.1489 & 1 & 166859.1489 & 0.9149 & 0.3563 \\
$X_{1}^{2}$ & 977.5129 & 1 & 977.5129 & 0.0054 & 0.9428 \\
$X_{2}^{2}$ & 4319.5104 & 1 & 4319.5104 & 0.0237 & 0.8801 \\
$X_{3}^{2}$ & 3810229.0896 & 1 & 3810229.0896 & 20.8916 & 0.0005 \\
$X_{1} X_{2}$ & 1441788.8260 & 1 & 1441788.8260 & 7.9054 & 0.0147 \\
$X_{1} X_{3}$ & 342278.8417 & 1 & 342278.8417 & 1.8767 & 0.1939 \\
$X_{2} X_{3}$ & 117200.6145 & 1 & 117200.6145 & 0.6426 & 0.4372 \\
Model & 7043698.0847 & 9 & 782633.1205 & 4.29119 & 0.0173 \\
Residual & 2370956.1843 & 13 & 182381.2449 & & \\
Lack of fit & 1382470.5784 & 5 & 276494.1157 & 2.23772 & 0.1124 \\
Pure error & 988485.6059 & 8 & 123560.7007 & &
\end{tabular}

Corrected total $9414654.2690 \quad 22$

Note: DF: degrees of freedom.

The predicted optimum values of wheat brans/apple pomace, $\left(\mathrm{NH}_{4}\right)_{2} \mathrm{SO}_{4}$ and solid/liquid ratio were $3.3 / 6.7,0.86 \%$ and $1 / 3$, respectively. Validation using the predicted optimum conditions was conducted and the polygalacturonase production was determined to be $3912.21 \mathrm{U} / \mathrm{g}$ dry substrate. It should be noted that the value was higher than any of those in the initial experiments and close to the predicted value, indicating that the optimization was reasonable and desirable.

3.3 Optimization of fermentation conditions for enhancing polygalacturonase production

3.3.1 Effects of initial medium $\mathrm{pH}$

Natural $\mathrm{pH}$ and 6.0 were found to be suitable for enhancing polygalacturonase production (Figure 2a), which is supported by the finding of Patil et al. ${ }^{[3]}$ Zasłona and Trusekhołownia ${ }^{[7]}$ have reported that the most promising production was obtained when the $\mathrm{pH}$ was 8.0. But Sethi et al. ${ }^{[9]}$ reported that $\mathrm{pH} 5.0$ was optimum for the production of pectinase by Aspergillus terreus NCFT 4269.10. The initial medium $\mathrm{pH}$ also influences the growth of microbes or shows impact upon the enzymatic activity.

The fermentation time, medium volume and inoculum load for (a) were $96 \mathrm{~h}, 10 \mathrm{~g}$ and $20 \times 10^{5}$ spores/g dry substrate, respectively. The $\mathrm{pH}$, medium volume and inoculum load for (b) were Natural, $10 \mathrm{~g}$ and $20 \times 10^{5}$ spores/g dry substrate, respectively. The $\mathrm{pH}$, fermentation time and inoculum load for (c) were Natural, $96 \mathrm{~h}$ and $20 \times 10^{5}$ spores/g dry substrate, respectively. The $\mathrm{pH}$, fermentation time and medium volume for (d) were Natural, $96 \mathrm{~h}$ and $10 \mathrm{~g}$, respectively.

It is generally known that the synthesis of polygalacturonase is related to the nitrogen compounds consumption and this might be due to the alkalization or acidification of medium ${ }^{[16]}$. In another word, the change of $\mathrm{pH}$ could be utilized to achieve relevant information on the commencement and retardation of polygalacturonases synthesis.

\subsubsection{Effects of fermentation time}

At constant $\mathrm{pH}$ (natural) and temperature $\left(28^{\circ} \mathrm{C}\right)$, polygalacturonase production was measured in varying fermentation periods. Based on the results shown in Figure 2b, it could be concluded that polygalacturonase production was enhanced at different levels and tended to stabilize at $4 \mathrm{~d}$ of incubation. Sethi et al. ${ }^{[9]}$ and Maller et al. ${ }^{[23]}$ have also reported that $A$. terreus and A. niveus produced pectinase optimally at $4 \mathrm{~d}$ of incubation, which is in agreement with current finding in this research. But the maximum polygalacturonase activity was observed after $3 \mathrm{~d}$ by using Penicillium variotii ${ }^{[3]}$ and Penicillium chrysogenum $^{[7]}$, and at $5 \mathrm{~d}$ by using Penicillium atrovenetum ${ }^{[24]}$, respectively. The reason might be that the natural substrate induced the enzyme production at various phase for different strains.

\subsubsection{Effects of medium volume}

Polygalacturonase was produced at $28^{\circ} \mathrm{C}$ and natural $\mathrm{pH}$ for 4 $\mathrm{d}$ with supplementation of medium volume. It was found that the maximum catalytic activity was obtained at medium volume of $10 \mathrm{~g} / 250 \mathrm{~mL}$ (Figure 2c). Further increase on volume resulted in a decrease in enzyme production and this might be due to the aerobic respiration of $P$. expansum 3.5425 .

3.3.4 Effects of inoculum load

To evaluate the impact of inoculum load on polygalacturonase production, $1-200 \times 10^{5}$ spores/g dry substrate inoculums were applied in SSF medium and the enzymatic activity was measured. 
It was obtained that the production of polygalacturonase was maximized with the inoculum load of $2 \times 10^{6}$ spores/g dry substrate (Figure 2d). However, enzymatic synthesis decreased with the further increase of inoculum load, probably owing to the depletion of the nutrients in the fermented medium, as observed in $B$. firmus $^{[25]}$.

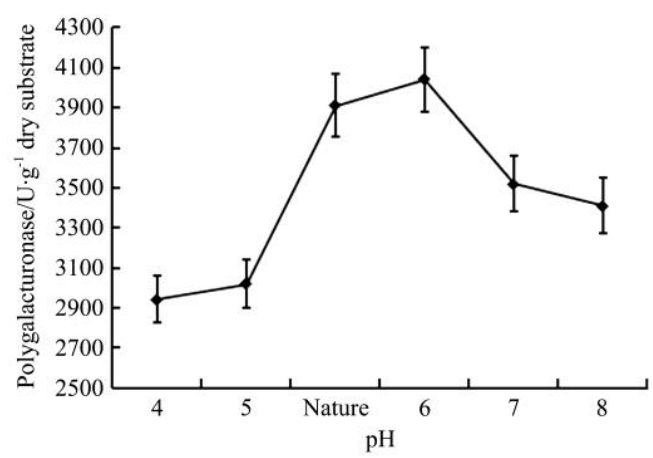

a. Effects of $\mathrm{pH}$ on polygalacturonase production

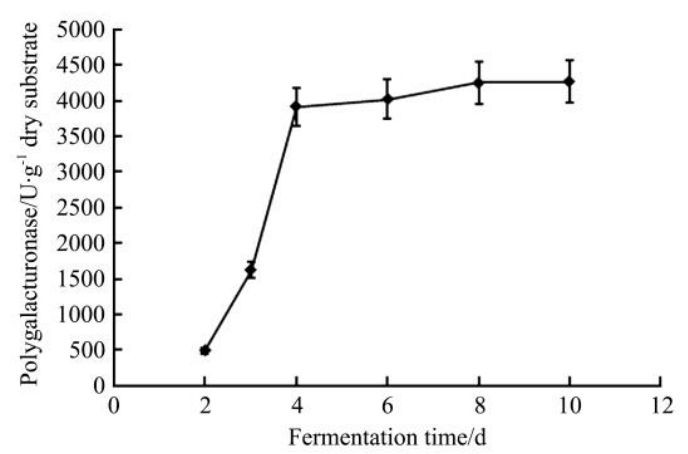

b. Effects of fermentation time on polygalacturonase production

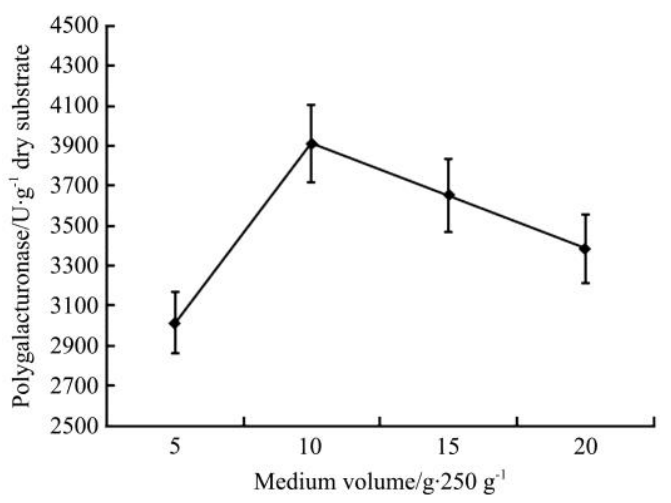

c. Effects of medium vloume on polygalacturonase production

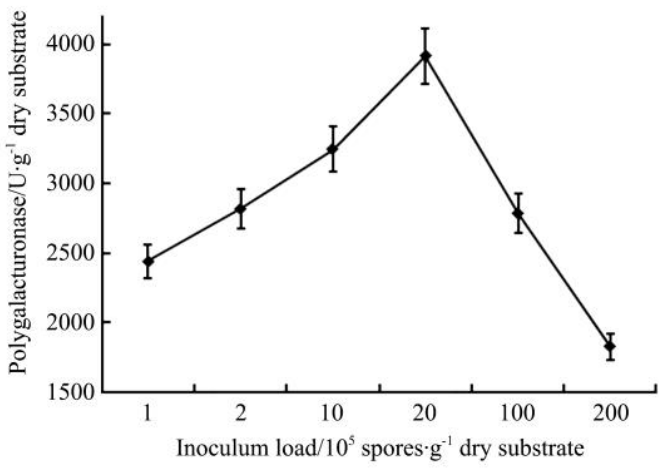

d. Effects of inoculum load on polygalacturonase production

Figure 2 Effects of fermentation parameters on polygalacturonase production

\subsection{Polygalacturonase purification}

Polygalacturonase produced by $P$. expansum 3.5425 in SSF was purified using a combination of ammonium sulfate precipitation, ion-exchange and gel filtration methods. The results of polygalacturonase purification are presented in Table 4 .

Table 4 Purification protocol for polygalacturonase from Penicillium expansum $\mathbf{3 . 5 4 2 5}$

\begin{tabular}{cccccc}
\hline Purification step & $\begin{array}{c}\text { Total } \\
\text { activity } \\
/ \mathrm{U} \cdot \mathrm{mL}^{-1}\end{array}$ & $\begin{array}{c}\text { Total protein } \\
/ \mathrm{mg} \cdot \mathrm{mL}^{-1}\end{array}$ & $\begin{array}{c}\text { Specific } \\
\text { activity } \\
/ \mathrm{U}^{-1} \mathrm{mg}^{-1}\end{array}$ & $\begin{array}{c}\text { Purification } \\
\text { folds }\end{array}$ & $\begin{array}{c}\text { Yield } \\
1 \%\end{array}$ \\
\hline $\begin{array}{c}\text { Crude extract } \\
\text { Ammonium sulfate } \\
\text { precipitation }\end{array}$ & 1102.64 & 0.86 & 1282.14 & 1.00 & 100 \\
$\begin{array}{c}\text { HiTrap CMFF } \\
\text { Sephadex G-75 }\end{array}$ & 473.71 & 0.05 & 9474.20 & 7.39 & 42.96 \\
\hline
\end{tabular}

The crude extract was purified 2.13-fold by ammonium sulfate. Among the three different fractions which were eluted from the CMFF column, the second peak eluted by $0.5 \mathrm{M} \mathrm{NaCl}$ showed the highest enzymatic activity (Figure $3 \mathrm{a}$ ). The active fractions were pooled, concentrated and applied to a Sephadex G-75 chromatography for further purification. As shown in Figure 3b, fractions having enzymatic activity occurred in the first peak. The purified enzyme was finally obtained with a purification fold of

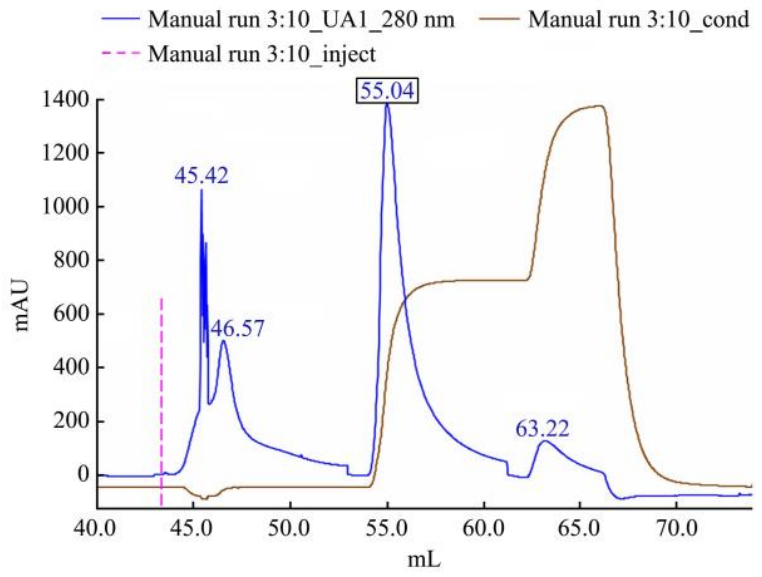

a. HiTrap CMFF chromatography

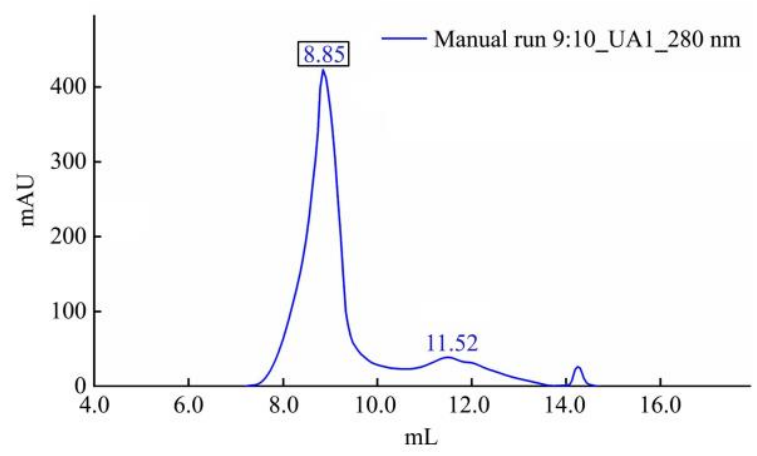

b. Superdex G-75 gel filtration chromatography

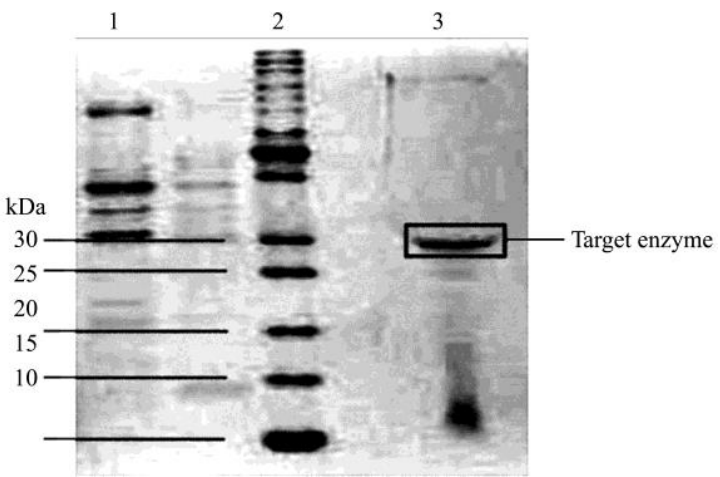

c. SDS-PAGE. 1 Crude enzyme, 2 the protein molecular weight marker, 3 purified enzyme 
Figure 3 Purification results and SDS-PAGE analysis of polygalacturonase

15.03 and its yield was $17.48 \%$ after three methods. It is reported that polygalacturonase produced by $P$. solitum was purified with a lower yield of $5.77 \%$ and a purification fold of $3.2^{[26]}$, but it is meaningless to compare because of the inter-laboratory variations ${ }^{[27]}$. The purity and molecular weight was measured by SDS-PAGE (Figure 3c). A single band observed in Fig. 3c was about $30 \mathrm{kDa}$.

\subsection{Effects of temperature, $\mathrm{pH}$ and metal ions on enzymatic} activity

Temperature and $\mathrm{pH}$ are two important indexes to influence the enzymatic activity. In this study, the activity of polygalacturonase reaches its maximum at temperature $50^{\circ} \mathrm{C}$ (Figure 4a) and $\mathrm{pH}$ 3-5 (Figure 4b). The optimum temperature of reported polygalacturonase varied from $30^{\circ} \mathrm{C}-69^{\circ} \mathrm{C}$, and the optimal $\mathrm{pH}$ was in acidic conditions ${ }^{[27,28]}$, which is in agreement with this research.

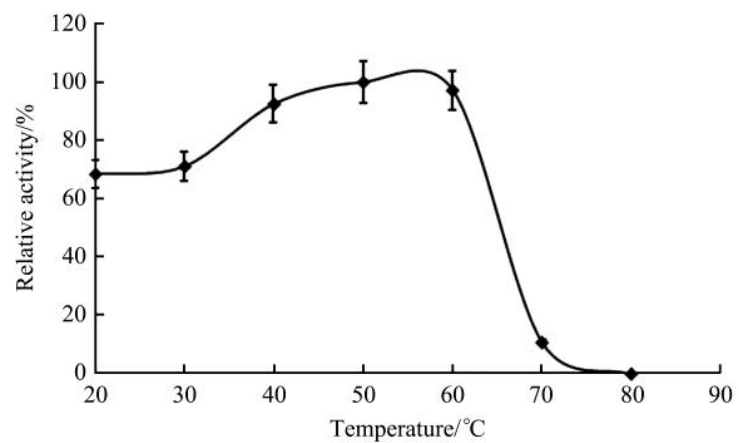

a. Effects of temperature on polygalacturonase activity

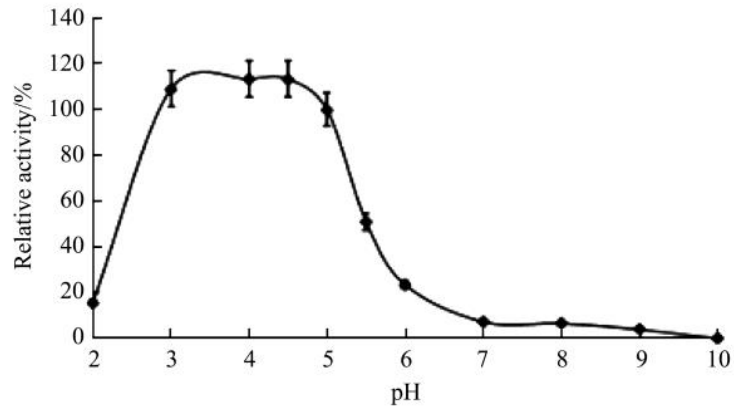

b. Effects of $\mathrm{pH}$ on polygalacturonase activity

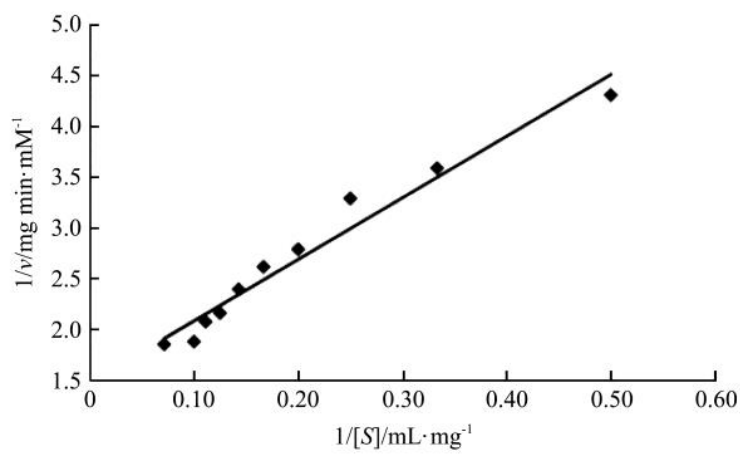

c. Lineweaver-Burk plot

Figure 4 Characterization of purified polygalacturonase

The influences of several metal ions on polygalacturonase activity are presented in Table 5. Among the various cations, $\mathrm{Mg}^{2+}, \mathrm{Mn}^{2+}$ and $\mathrm{Cu}^{2+}$ enhanced the enzymatic activity significantly, whereas $\mathrm{Al}^{3+}$ showed an inhibiting effect.

\subsection{Kinetic parameters of purified polygalacturonase}

The values of $K_{\mathrm{m}}$ and $V_{\max }$ of the enzyme were calculated by Lineweaver-Burk plot and are shown in Figure 4c. The $K_{\mathrm{m}}$ value was $4.09 \mathrm{mg} / \mathrm{mL}$ and the corresponding $V_{\max }$ was $674.76 \mu \mathrm{M} /(\mathrm{min} \cdot \mathrm{mg})$ The $K_{\mathrm{m}}$ represents affinity between enzyme and substrate and its value in this study is in agreement with the reports in which the $K_{\mathrm{m}}$ value of polygalacturonase produced by Penicillium sp. ranges from 0.059 to $4.7 \mathrm{mg} / \mathrm{mL}^{[28]}$.

Table 5 Effects of cations on polygalacturonase activity

\begin{tabular}{|c|c|c|}
\hline Metal ion & Concentration/mM & Relative activity $/ \%$ \\
\hline Contol & & $100.00 \pm 0.00$ \\
\hline \multirow{3}{*}{$\mathrm{K}^{+}$} & 0.5 & $98.91 \pm 3.59$ \\
\hline & 1.0 & $98.02 \pm 5.76$ \\
\hline & 1.5 & $97.62 \pm 4.93$ \\
\hline \multirow{3}{*}{$\mathrm{Na}^{+}$} & 0.5 & $94.16 \pm 3.88$ \\
\hline & 1.0 & $95.45 \pm 5.59$ \\
\hline & 1.5 & $93.07 \pm 6.01$ \\
\hline \multirow{3}{*}{$\mathrm{Ca}^{2+}$} & 0.5 & $100.20 \pm 6.14$ \\
\hline & 1.0 & $94.55 \pm 6.89$ \\
\hline & 1.5 & $95.64 \pm 5.03$ \\
\hline \multirow{3}{*}{$\mathrm{Mg}^{2+}$} & 0.5 & $110.50 \pm 5.69$ \\
\hline & 1.0 & $113.47 \pm 2.43$ \\
\hline & 1.5 & $108.32 \pm 7.80$ \\
\hline \multirow{3}{*}{$\mathrm{Mn}^{2+}$} & 0.5 & $176.73 \pm 5.85$ \\
\hline & 1.0 & $175.64 \pm 4.31$ \\
\hline & 1.5 & $184.46 \pm 7.67$ \\
\hline \multirow{3}{*}{$\mathrm{Cu}^{2+}$} & 0.5 & $116.73 \pm 1.59$ \\
\hline & 1.0 & $132.67 \pm 2.19$ \\
\hline & 1.5 & $132.08 \pm 3.23$ \\
\hline \multirow{3}{*}{$\mathrm{Zn}^{2+}$} & 0.5 & $99.01 \pm 1.52$ \\
\hline & 1.0 & $104.06 \pm 2.63$ \\
\hline & 1.5 & $104.36 \pm 2.32$ \\
\hline \multirow{3}{*}{$\mathrm{Fe}^{2+}$} & 0.5 & $94.46 \pm 2.59$ \\
\hline & 1.0 & $96.63 \pm 1.88$ \\
\hline & 1.5 & $104.16 \pm 4.27$ \\
\hline \multirow{3}{*}{$\mathrm{Al}^{3+}$} & 0.5 & $88.61 \pm 3.35$ \\
\hline & 1.0 & $95.25 \pm 4.93$ \\
\hline & 1.5 & $93.56 \pm 4.06$ \\
\hline
\end{tabular}

\subsection{Apple juice clarification by partially purified enzyme}

Clarity $\left(\% \mathrm{~T}_{660 \mathrm{~nm}}\right)$ is a crucial indicator of clarified juice. Enzyme concentration is one of the most important indexes affecting the juice clarification ${ }^{[29]}$. In the apple juice clarification, it was observed that with $0.3 \mathrm{~mL} / \mathrm{kg}$ partially purified polygalacturonase $(875.15 \mathrm{U} / \mathrm{mL})$ application, the pectin was almost fully degraded after $1 \mathrm{~h}$ incubation at $50^{\circ} \mathrm{C}$ and natural $\mathrm{pH}$. However, the maximum clarity $\left(\% \mathrm{~T}_{660 \mathrm{~nm}}=94.9\right)$ of the juice was attained in presence of $0.4 \mathrm{~mL} / \mathrm{kg}$ enzyme (Figure 5a). Further increase of partially purified polygalacturonase concentration resulted in a slightly decrease in clarity and this might be due to that the color of the enzyme solution affected the measurement of juice. Figure $6 \mathrm{a}$ shows the effect of enzyme concentration on clarification. With enzymatic treatment, the pectin molecules were broken down by polygalacturonase, which promoted the formation of pectin-protein flocs leaving a clear supernatant and remarkably removing the colloidal part ${ }^{[19,30]}$.

In this study, a high clarity of $94.9 \%$ was obtained in presence of polygalacturonase $(875.15 \mathrm{U} / \mathrm{mL})$, which is similar to the results reported by Dey and Banerjee ${ }^{[19]}$. It showed a great potential of polygalacturonase produced by $P$. expansum 3.5425 .

For further enhancing the clarity of apple juice with $0.4 \mathrm{~mL} / \mathrm{kg}$ partially purified polygalacturonase, the $\mathrm{pH}$, temperature and incubation time were optimized. As shown in Figures 5b-5d, the juice clarity was maximum at $\mathrm{pH} 2.5-4.5,45^{\circ} \mathrm{C}$ and 90 min holding time, respectively. Accordingly, the clarification effects are 
shown in Figures 6b-6d, respectively, indicating the clarity was high in the optimum conditions. It was noticed that further increase in $\mathrm{pH}$ and temperature resulted in a significant decrease in clarity, while further increase in incubation time made a constant clarity. In view of the adverse impact of long incubation time on the quality of apple juice, $90 \mathrm{~min}$ was suggested. In addition, the natural $\mathrm{pH}$ of apple juice was in a range of 3.2-4.5, which was in the range of 2.5-4.5 (optimal $\mathrm{pH}$ for the maximal clarity). Hence, the natural $\mathrm{pH}$ was chosen to clarify the apple juice in present study.

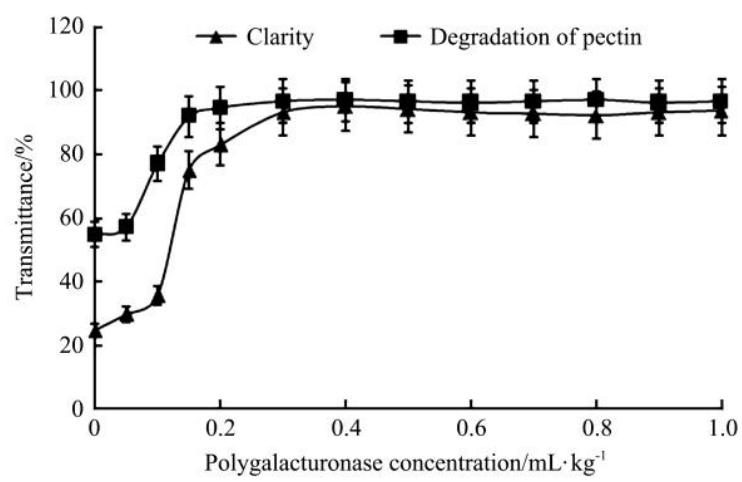

a. Polygalacturonase concentration

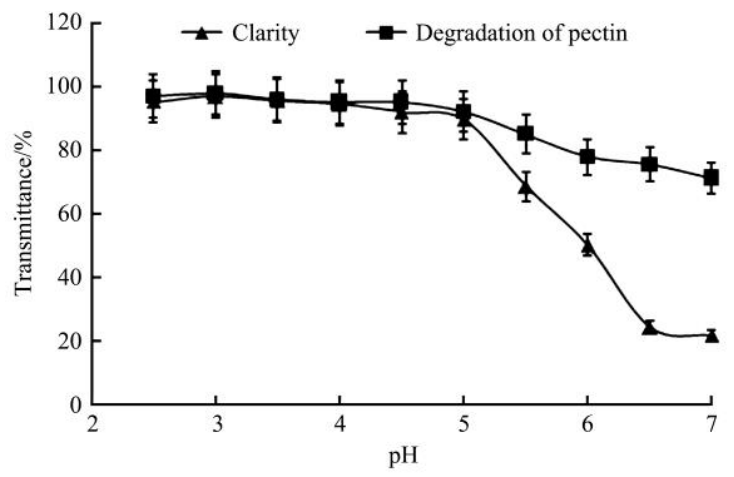

b. $\mathrm{pH}$

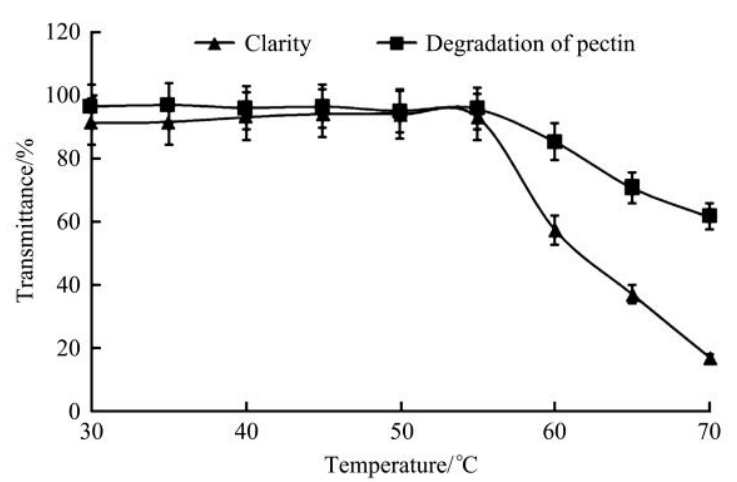

c. Temperature

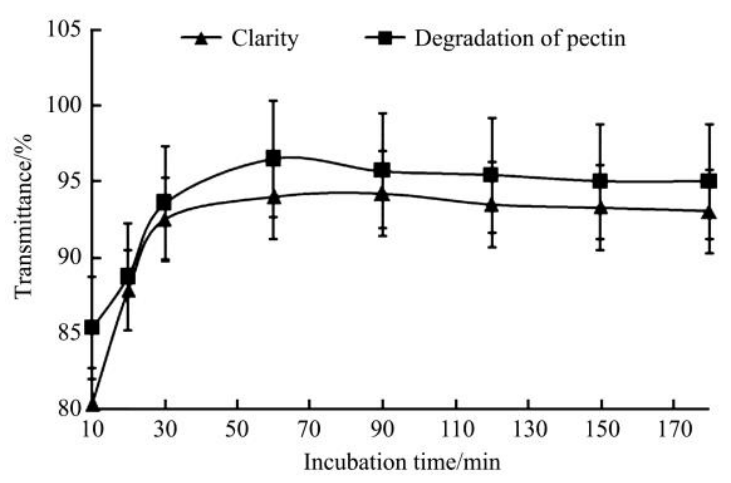

d. Incubation time

Figure 5 Effects of enzyme treatment parameters on the clarity of apple juice

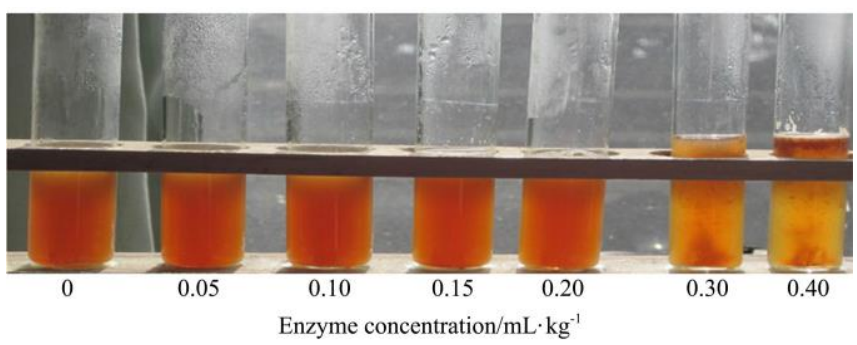

a. Effects of enzyme concentrationon the clarity

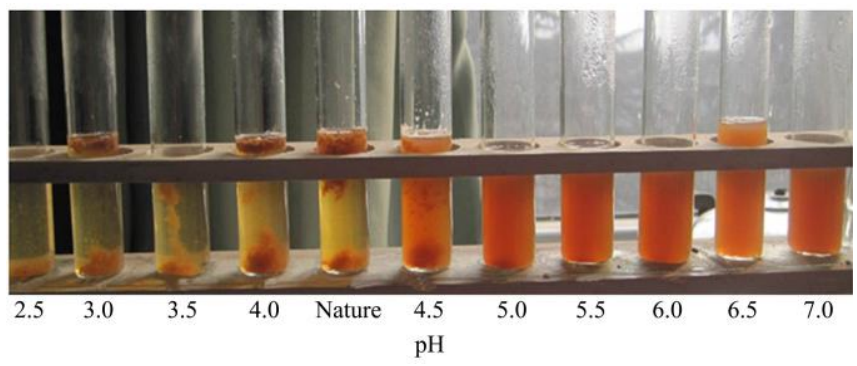

b. Effects of $\mathrm{pH}$ on the clarity

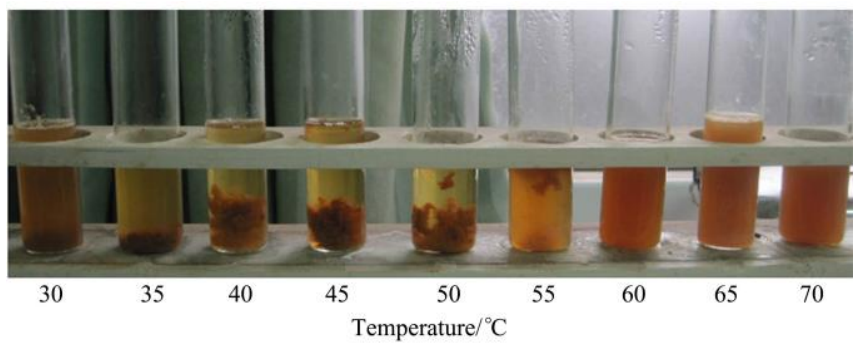

c. Effects of temperature on the clarity

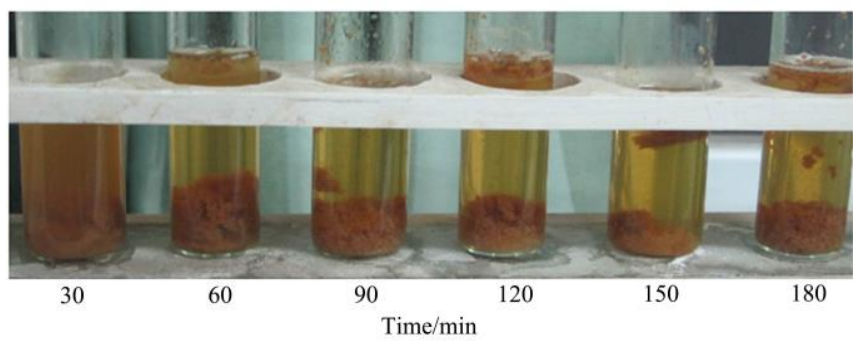

d. Effects of incubation time on the clarity

Figure 6 Pictures of apple juice clarification

\section{Conclusions}

Apple pomace and wheat bran, common agricultural wastes, could be utilized as good substrates for enhancing polygalacturonase production from $P$. expansum 3.5425 by solid-state fermentation. Significant improvement in polygalacturonase production was achieved by ROD combined with fermentation optimization. The purified polygalacturonase showed activity in a wide $\mathrm{pH}$ and temperature range, which makes it more acceptable in food industry. By applying the enzyme in apple juice clarification, a high clarity was achieved. In conclusion, this study presented a cost-effective and environmental approach to effectively utilize the agricultural wastes and promoted the polygalacturonase production.

\section{Acknowledgements}

The authors would like to thank the High-Level Talent Scientific Research Staring Foundation (No. 2015015) provided by 
Henan Institute of Science \& Technology, Key Scientific Research Project (17A550001) supported by Education Department of Henan Province, Program for Innovative Research Talents (in Science and Technology) of Henan Provincial University (16HASTIT015) and Excellent Youth Foundation of Henan Scientific Committee (174100510003).

\section{[References]}

[1] Fontana R C, da Silveira M M. Production of polygalacturonases by Aspergillus oryzae in stirred tank and internal- and external-loop airlift reactors. Bioresource Technology, 2012; 123: 157-163.

[2] Tepe O, Dursun A Y. Exo-pectinase production by Bacillus pumilus using different agricultural wastes and optimizing of medium components using response surface methodology. Environmental Science and Pollution Research, 2014; 21(16): 9911-9920.

[3] Patil N P, Patil K P, Chaudhari B L, Chincholkar S B. Production, purification of Exo-Polygalacturonase from soil isolate paecilomyces variotii NFCCI 1769 and its application. Indian Journal of Microbiology, 2012; 52(2): 240-246.

[4] Demir H, Tar1 C. Valorization of wheat bran for the production of polygalacturonase in SSF of Aspergillus sojae. Industrial Crops and Products, 2014; 54: 302-309.

[5] Kashyap D R, Vohra P K, Chopra S, Tewari R. Applications of pectinases in the commercial sector a review. Bioresource Technolology, 2001; 77: 215-227.

[6] Castilho L R, Medronho R A, Alves T L M. Production and extraction of pectinases obtained by solid state fermentation of agroindustrial residues with Aspergillus niger. Bioresource Technolology, 2000; 71: 45-50.

[7] Zasłona H, Trusekhołownia A. Enhanced production of polygalacturonase in solid-state fermentation: selection of the process conditions, isolation and partial characterization of the enzyme. Acta Biochimica Polonica, 2015; 62(4): 651.

[8] Kumar Y S, Varakumar S, Reddy O V S. Production and optimization of polygalacturonase from mango ( Mangifera indica L.) peel using Fusarium moniliforme in solid state fermentation. World Journal of Microbiology and Biotechnology, 2010; 26(11): 1973-1980.

[9] Sethi B K, Nanda P K, Sahoo S. Enhanced production of pectinase by Aspergillus terreus NCFT 4269.10 using banana peels as substrate. 3 Biotech, 2016; 6(1): 36-51.

[10] Demir H, Gogus N, Tari C, Heerd D, Lahore M F. Optimization of the process parameters for the utilization of orange peel to produce polygalacturonase by solid-state fermentation from an Aspergillus sojae mutant strain. Turkish Journal of Biology, 2012; 36: 394-404.

[11] Illková, K., Zemkov Z, Flodrov D, Ger J, Benkovsk D, Omelkov J, et al. Production of Geotrichum candidum polygalacturonases via solid state fermentation on grape pomace. Chemical Papers, 2012; 66(9): 852-860.

[12] Tai E S, Hsieh P C, Sheu S C. Effect of polygalacturonase and feruloyl esterase from Aspergillus tubingensis on demucilage and quality of coffee beans. Process Biochemistry, 2014; 49(8): 1274-1280.

[13] Patidar M K, Nighojkar S, Kumar A, Nighojkar A. Papaya peel valorization for production of acidic pectin methylesterase by Aspergillus tubingensis and its application for fruit juice clarification. Biocatalysis and Agricultural Biotechnology, 2016; 6: 58-67.

[14] Berovic M, Ostroversnik H. Production of Aspergillus niger pectolytic enzymes by solid state bioprocessing of apple pomace. Journal of Biotechnology, 1997; 53: 47-53.

[15] Taragano V, Sanchez V E, Pilosof A M R. Combined effect of water activity depression and glucose addition on pectinase and protease production by Aspergillus niger. Biotechnology Letters, 1997; 19: 233-236.

[16] Zeni J, Cence K, Grando C E, Tiggermann L, Colet R, Lerin L A, et al Screening of pectinase-producing microorganisms with polygalacturonase activity. Applied Biochemistry and Biotechnology, 2011; 163(3): 383-392.

[17] Miller G L. Use of dinitrosalicylic acid reagent for determination of reducing sugar. Analytical Chemistry, 1959; 31: 426-428.

[18] Bradford M M. A rapid and sensitive method for the quantitation of microgram quantities of protein utilizing the principle of protein-dye binding. Analytical Biochemistry, 1976; 72(1-2): 248-254.

[19] Dey T B, Banerjee R. Application of decolourized and partially purified polygalacturonase and alpha-amylase in apple juice clarification. Brazilian Journal of Microbiology, 2014; 45(1): 97-104.

[20] Fang T J, Liao B C, Lee S C. Enhanced production of xylanase by Aspergillus carneus M34 in solid-state fermentation with agricultural waste using statistical approach. Nature Biotechnology, 2010; 27(1): 25-32.

[21] Sharma S, Mandhan R P, Sharma J. Utilization of agro-industrial residues for pectinase production by the novel strain Pseudozyma sp. SPJ under solid state cultivation. Annals of Microbiology, 2011; 62(1): 169-176.

[22] Fang J, Cao Y, Matsuzaki M, Suzuki H. Effects of apple pomace proportion levels on the fermentation quality of total mixed ration silage and its digestibility, preference and ruminal fermentation in beef cows. Animal Science Journal, 2016; 87(2): 217-23.

[23] Maller A, Damasio A R, da Silva T M, Jorge J A, Terenzi H F, Polizeli Mde L. Biotechnological potential of agro-industrial wastes as a carbon source to thermostable polygalacturonase production in Aspergillus niveus. Enzyme Research, 2011; 2011(1): 1-6.

[24] Adeleke A J, Ayodele Odunfa S, Olanbiwonninu A, Owoseni M C. Production of cellulase and pectinase from orange peels by fungi. Nature and Science, 2012; 10(5): 107-112.

[25] Reda A B, Hesham M Y, Mahmoud A S, Ebtsam Z A A. Production of bacterial pectinase(s) from agro-industrial wastes under solid state fermentation conditions. Journal of Applied Sciences Research, 2008; 4(12): 1708-1721

[26] Jurick W M, Vico I, Gaskins V L, Garrett W M, Whitaker B D, Janisiewicz W J, et al. Purification and biochemical characterization of polygalacturonase produced by penicillium expansum during postharvest decay of 'Anjou' pear. Phytopathology, 2010; 100(1): 42-48.

[27] Jacob N, Asha Poorna C, Prema P. Purification and partial characterization of polygalacturonase from Streptomyces lydicus. Bioresource Technology, 2008; 99(14): 6697-701.

[28] Jayani R S, Saxena S, Gupta R. Microbial pectinolytic enzymes: A review. Process Biochemistry, 2005; 40(9): 2931-2944.

[29] Pinelo M, Zeuner B, Meyer A S. Juice clarification by protease and pectinase treatments indicates new roles of pectin and protein in cherry juice turbidity. Food and Bioproducts Processing, 2010; 88(2-3): 259-265.

[30] Alvarez S, Alvarez R, Riera F A, Coca J. Influence of depectinization on apple juice ultrafiltration. Colloids and Surfaces A: Physicochemical and Engineering Aspects, 1998; 138: 377-382. 